\title{
IAMJ
}

INTERNATIONAL

AYURVEDIC

MEDICAL JOURNAL

\section{EFFECT OF HARIDRA DHUMAPANA AND SVASAKUTARA RAS IN TAMAKA SVASA - A COMPARATIVE STUDY}

\author{
Sankramma Patil ${ }^{1}$, Pradeep J. $\mathbf{M}^{2}$, Manjunatha N. $\mathbf{S}^{3}$ \\ ${ }^{1}$ Assistant Professor, Dept. of Prasooti Evam Stree Roga, Vivek Ayurveda Medical College, Bijnor, U P, India \\ ${ }^{2}$ Professor; HOD Dept. of Panchakarma, Vivek Ayurveda Medical College, Bijnor, U P, India \\ ${ }^{3}$ Professor; HOD Dept. of Swasthavritta, Kunwar Shekhar Vijendra Ayurved Medical College; Research Centre, \\ Shobhit University, Gangoh, UP, India
}

Corresponding Author: pradeepjm1628@gmail.com

https://doi.org/10.46607/iamj01p5022021

(Published Online: January 2021)

Open Access

(C) International Ayurvedic Medical Journal, India 2021

Article Received: 04/11/2020 - Peer Reviewed: 08/11/2020 - Accepted for Publication: 18/11/2020

\section{(A) Check for updates}

\section{ABSTRACT}

The incidence of the illness is too high in India as the cities here are exposed to some of the highest air pollution levels in the world. Added to this incidence of this illness, it may be crippling by virtue of its episodic, chronic course incapacitating the patient in his occupation. Moreover, as Acarya Caraka says the disease tend to incriminate the heart in the long run threatening one's life. This illness is found to be mind boggling to the physician even. In spite of prescribing best available medicine, the complete cure proved impossible in many. Further, in some, managing the attacks seems to be difficult. In spite of weeping and wailing of the patients the physician's sincere attempts tend to be vain. This is true for the conventional medicine and for any of the alternative medicine. Vata and Kapha are the two key pathological factors involved in the Samprapti of Tamaka Svasa demands distinct remedy and hence writing a prescription in such a situation is wheels in wheels. Dhumapana is one of the lines of treatment is explained in Caraka Samhita. Dhumapana has its own importance as the medicine is directly delivered into the Pranavaha Srotas and there by initiates rectification of morbidity. Thus, this comparative study planned to evaluate the therapeutic effect of Haridra Dhumapana and Svasakutara Rasa in patients suffering from Tamaka Svasa. Total 20 patients were included and treated with obsevertaion of 7 days under two groups (dhumapana group \& Svasakutara ras grop). Finally, it was concluded that Dhumapana group comparatively better relief to the patients of Tamaka Svasa. 
Keywords: Tamaka shvasa, Dhumapana, Asthama, Svasakutara ras

\section{INTRODUCTION}

The presentation of the Pranavaha Srotas disorders is more emblematic. Among which Tamaka Svasa is one, well known for its episodic chronic course ${ }^{[1]}$. In modern parlance, this illness is best compared to Bronchial asthma. A recent publication by the "The global burden of asthma report'" ${ }^{[2]}$ reveals that about 50 million people suffer from Bronchial Asthma in Central and Southern Asia. The report also predicts the prevalence of the illness tend to increase in the coming years. It also points out that the increase in prevalence of the illness is due to increase in industrialization as well as urbanization. "Visheshat Durdina Tamyethi Svasaha Sa Tamaka Mataha", "3] The attack of Svasa with Tamaprapvesh, which occurs especially during durdina, is referred by the name Tamaka Svasa. "Svasasthu bhasthrikadmana samavathordwa gamini", [4]

This means it is a disease where the expiration of air produces a sound similar to the sound of bellow of black smith. These features are similar to that of Bronchial asthma in modern parlance. The word Asthma is derived from Greek, which means hard drawn breath or panting. Briefly, the union of two words Tamaka and Svasa forms the word Tamaka Svasa. Tamaka refers to the darkness in front of the eyes or else the disease predominating at night hours. Svasa refers to labored breathing producing sound.

Along with so many Ahara (food) \& Vihara (activity) factors, some of the environmental factors include cold weather, cloudy weather, dust, smoke etc. In addition, every person living in this environment is exposed to these etiological factors of the Tamaka Sva$s a$. However, it is observed that in a hostile environment only the patient suffering from the Tamaka Sva$s a$ will develop the attack of Svasa and not all the persons.

Samprapthi: Predominant morbidity of Vata and Kapha Dosha, morbid Dosha stemming out from Pittasthana, affliction of Rasa Dhatu, disturbed functioning of the Pranavaha Srotas are the hall marks of pathogenesis of Tamaka Svasa. And this unique pa- thology determines episodic nature of the illness that runs a chronic course and in the long run incriminating the Hridaya Marma the root of Pranavaha Srotas. Pathologic cause of symptom manifestation: Accumulation of Sleshma when obstructs the Pranavaha Srotas, it predisposes to productive cough and is a predominant symptom of Tamaka Svasa. As the sputum is brought out, the obstruction is temporarily relieved and hence the patients feel easy to breathe. The morbid Kapha Dosha in conjunction with Rasa Dhatu causes abnormal production of Sleshma in the Pranavaha Srotas. This Sleshma is described as thick, sticky and tenacious and thereby contributes the obstruction in the Pranavaha Srotas. Excessively secreted tenacious Sleshma is expectorated out with much difficulty during the bouts of coughing. The Kanta Ghurghuraka or the rattling sound is also suggestive of increased Sleshma. ${ }^{05]}$

Rupa [6-14] Svasa, Kasa' Kapha Nistivana' Kantha Gurghuraka, Peenasa

Onset: Sudden onset and rapid development of an attack of breathlessness is characteristic of Tamaka Svasa. Alternatively depending upon the virulence of Doshic vitiation the mode of onset may vary from insidious, gradual to acute manifestation. Manifestation of the Rupa of Tamaka Svasa preceded by the occurrence of Poorvarupa that are mostly related to Annavaha Srotas and Pranavaha Srotas is the typical onset of the illness. In some patients, the episode of Tamaka Svasa may start with Peenasa and related symptoms. In some others, irritant cough may be the initial symptom. Yet other patients may have trouble in breathing in the form of tightness of the chest, followed by the development of other symptoms.

Severity: Depending upon the amount of Doshic vitiation and its virulence the severity of an attack of Tamaka Svasa may vary from attack to attack. The individual attack may be mild, moderate or severe. In a worst attack, the patients' speech is restricted to a word or even lesser than that. Along with this perspi- 
ration may also be seen on the forehead. At times, the consciousness of the patient may deteriorate.

Course: Depending upon the exposure to the predisposing factors the illness shows recurrent attacks of Tamaka Svasa. When the disease runs a chronic course, due to the damage to the Pranavaha Srotas, the episodic nature of the illness may cease; rather it will become a continuous illness. In the terminal stages, the pathogenesis extends to the Hridayamarma and hence the symptoms of Hridayamarmabhigata may supervene.

Dhumapana: Smoking for the therapeutic purposes using a specially designed instrument or pipe is known by the name Dhumapana. Using a special instrument, the herbal powders are burnt, and the smoke emitted is inhaled. ${ }^{[15]}$ The accumulation of the Kapha Dosha in the head as well as respiratory system is best cleared by this procedure. Following Vamana karma and Nasya Karma therapeutic smoking is practiced as a follow up procedure. In disorders like Tamaka Sva$s a$, Peenasa, Sirasula therapeutic smoking is an effective treatment in relieving the symptoms by clearing the passages. ${ }^{[16]}$

\section{Method of administration of Dhuma.}

To begin with the patient is thoroughly examined to confirm the indications as well as to rule out any of the contraindications. Then the patient is made to sit in a knee highchair with his body erect and looking forwards. He should have full concentration on the therapy and should not have any reason for distraction of mind like Kama, Krodha, Bhaya etc. The Dhumayantra is prepared and its functioning is assessed. Then the patient is asked to inhale the Dhuma through the mouthpiece of the instrument. And then the patient is allowed to exhale the Dhuma only through the mouth. If the patient has symptoms related to the nose and head, the Dhuma may be inhaled through the nose and is once again exhaled through the mouth. When the patient inhales three puffs of Dhuma it is counted as one bout of Dhumapana. Patient is allowed a small pause between each bout of smoking. In these way three bouts of Dhumapana is carried out in a single sitting. During the procedure if the sputum comes out the patient is asked to spit out the sputum.
Aim of Study: This study is planned to evaluate the therapeutic effect of the Haridra Dhumapana in patients suffering from Tamaka Svasa. Following are the objectives of the study.

1. To evaluate the KaphaVatahara effect of Haridra Dhumapana and Svasakutara rasa in patients suffering from Tamaka Svasa and there by assessing the therapeutic effect of these medications in bringing symptomatic relief.

2. To explore the efficacy of the combination in the management of Tamaka Svasa.

Source of Data: The patients who attended the OPD and IPD section of our Ayurveda hospital having the symptoms like breathlessness and cough with a tentative diagnosis of Tamaka Svasa were screened. Among these patients only 20 patients who fulfilled the below mentioned criteria of inclusion were taken for the study. While selecting these 20 patients care was also taken to see that there was not any factor in these patients listed in the exclusion criteria. The selected patient's detailed profile is prepared as per the detailed proforma designed for the same purpose, which incorporates relevant data like symptomatology, physical signs, laboratory investigation reports, as well as assessment criteria.

Plan of the Study: In the present clinical study, a total number of 20 patients suffering from Tamaka Sva$s a$ were taken from OPD and IPD of our Ayurveda College Hospital. All the 20 patients completed the scheduled regimen. In these patients the diagnosis was based on signs and symptoms of Tamaka Svasa as well as spirometric parameters. As a routine, Hematological investigations were carried out in all the patients taken for the study. The selected 20 patients were segregated in two groups irrespective of their age sex or cast. Each group consisted of 10 patients. The first group consisting of 10 patients is treated as test group and is named as Dhumapana group. The second group is taken as control group and is called as Svasakutara rasa group.

The patients of Dhumpana group were subjected to seven days course of Haridra Dhumapana along with oral administration of Svasakutara rasa in a dose of $250 \mathrm{mg}$ thrice daily for ten days. The patients in the 
Svasakutara rasa group were treated orally with Svasakutara rasa in a dose of $250 \mathrm{mg}$ thrice daily for consecutive ten days.

\section{Inclusion Criteria:}

20 patients taken in this clinical trail were according to the following Inclusion criteria: -

1. Patients with Pratyatma Laksana of Tamaka Sva$s a$ with the positive spirometric test for Bronchial asthma.

2. Patients age group between 12 to 70 Years.

3. A history of 6 months breathlessness, or more.

\section{Exclusion Criteria:}

The patients suffering from Tamaka Svasa showing the presence of following criteria were excluded from the study.

1. Patients below 12 years and above 70 years were excluded from the study.

2. Patients of Tamaka Svasa who also suffer from other systemic disorders like tuberculosis, diabetes mellitus, HIV, hepatitis, hypertension, complications of Bronchial asthma like Emphysema, Cor-pulmonale etc.

Investigations: Following is the list of investigations carried out in 20 patients of Tamaka Svasa taken for this study.

Blood- TC, DC, ESR, $\mathrm{Hb} \%$, other investigations if needed

Routine urine analysis

Spirometric test

$\mathrm{X}$-ray done wherever necessary.

Design: It is a single blind comparative clinical study with pre-test and post-test design. In this study 20 patients suffering from Tamaka Svasa of either sex of age group between 12 to 70 years were selected. These patients were randomly allocated into two groups. First test group is the Dhumapana group and in short, this group is referred as DPG. Svasakutara rasa group is the second group and is also the control group. This control group is also referred as SKG in short.

Intervention: In the Dhumapana group the patients were subjected to Haridra Dhumapana in a dose of one sitting per day for consecutive 7 days. Along with this Svasakutara rasa was orally administered in a dose of $250 \mathrm{mg}$ tid for ten days. This was the test group.

In the second Svasakutara rasa group, i.e. control group Svasakutara rasa was orally administered in a dose of $250 \mathrm{mg}$ tid for consecutive 10 days.

Assessment Criteria: The improvement or otherwise following the above said medication in the two groups was assessed before and after the treatment by adapting the standard methods of scoring the subjective as well as objective criteria. The spirometric evaluation of pulmonary ventilation was also carried out both before and after the treatment. The full account of the assessment criteria is elaborated in the following lines.

\section{Severity of Tamaka Svasa:}

1. Mild Intermittent:- Symptoms-symptoms $<2$ times a week, asymptomatic and normal PEF between exacerbations, brief exacerbation (few hours too few days), and intensity may vary, night time symptoms $<2$ times a month, lung function FEV, or PEF $60 \%$ to $80 \%$ predicted, $\mathrm{PEF}$ variability $>20 \%$

2. Mild Persistent: - Symptoms- symptoms $>2$ times a week but $<1$ time a day, exacerbation may affect activity, nighttime symptoms $>2$ times a month, lung function - FEV, or PEF $80 \%$ predicted PEF variability $20 \%$ to $30 \%$.

3. Moderate Persistent: - Symptoms - Daily symptoms, daily use of inhaled short acting beta2 agonist, exacerbations affect activity, exacerbations $>2$ times a week, may last for few days, lung Functions - FEV or PEV $60 \%$ to $80 \%$ predicted, $\mathrm{PEF}$ variability $>30 \%$.

4. Severe Persistent: - Continual symptoms, limited Physical activity affected with frequent exacerbation, nighttime symptoms - frequent, lung function - PEV or PEF $<60 \%$ of predicted, PEF variability $>30 \%$.

Breathlessness: Mild - Breathlessness with activity. Moderate - With talking. Severe - At rest. Impending respiratory failure-Breathlessness at rest.

Speech: Mild - Sentences. Moderate - Phrases. Severe - Words. Impending respiratory failure - Mute. 


\section{Cough:}

- Morning bouts or after exercise - Do not disturb work.

- Continuous cough during day and morning - Disturbing work.

- Continuous day morning and night cough - Disturbs activity.

- Continuous day, night and sleep and activity disturbed.

\section{Sputum:}

Less than $2.5 \mathrm{ml} /$ day.

$2.5 \mathrm{ml}$ to $1.5 \mathrm{ml} /$ day

15 to $25 \mathrm{ml} /$ day

$>25 \mathrm{ml} /$ day.

\section{Body position:}

Mild - Able to recline.

Moderate - Prefers sitting.

Severe - Unable to recline.

Impending respiratory failure - Unable to recline.

Respiratory Rate:

Mild - >10/min

Moderate - $>20 / \mathrm{min}$

Severe - After $>30 / \mathrm{min}$

Impending respiratory failure $>30 / \mathrm{min}$

Labored breathing:

Mild - Usually no use of accessory muscles.
Moderate - Commonly use of accessory respiratory muscles.

Severe - Usually use of accessory respiratory muscles.

Impending respiratory failure - Paradoxical thoracoabdominal movement.

\section{Breath Sounds:}

Mild - Moderate wheezing at mid to end expiration.

Moderate - Loud wheeze through out expiration.

Severe - Loud inspiration and expiratory wheezes.

Impending respiratory failure - Little air movement without wheezes (silent chest).

Spirometric Tests: Computerized electronic kit micro spirometer was used in this study for assessing pulmonary ventilation capacity. The technical features of this spirometer included-

Flow meter: Bi-directional digital turbine.

Range for flow measurement: 0.03 - $20 \mathrm{l} / \mathrm{s}$

Range for volume measurement: 101

Accuracy of measurement: $3 \%$ or $50 \mathrm{ml}$

Dynamic Resistance: @ 12 1/s $<0.7$ cmH2O/1/s

The interpretation of the predicted values for spirometric lung volumes was calculated and following the ERS 93 criteria (Official Statement of the European Respiratory Society, The European Respiratory Journal Volume 6, Supplement 16, and March 1993.) following is the list of spirometric tests, included in the present study on Tamaka Svasa.

\begin{tabular}{|l|l|l|}
\hline Symbol & UM & Parameter \\
\hline FVC & 1 (btps) Forced xpiratory & Vital Capacity \\
\hline FEV1 & 1 (btps) Forced xpiratory & Volume in 1 second \\
\hline PEF & $1 /$ sec Peak Expiratory & Flow \\
\hline FEV1/FVC $\%$ & FEV1 & as a percentage of FVC \\
\hline
\end{tabular}

Assessment of Overall effect: For assessing the overall effect of the treatment, the total scores of criteria of assessment of Tamaka Svasa after the treatment was considered. As per the reduction in the total scores of the overall effect is calculated as under:

Complete remission - Total score is 0 after the treatment.

Moderate Remission - Reduction in more than $60 \%$ of the initial score.

Average Remission - Reduction in score between 30 to $60 \%$.
Unchanged - Reduction less than $30 \%$ of the initial score.

Briefly, this assessment criteria incorporates almost all the subjective as well as objective clinical manifestations of the illness Tamaka Svasa.

\section{OBSERVATIONS AND RESULTS:}

A total of 20 patients suffering from Tamaka Svasa fulfilling the inclusion criteria were taken for the study. All these 20 patients who registered have completed the stipulated schedule of the study. These patients were randomly categorized into two groups of 
ten patients each irrespective of their age cast of creed. Ten patients were studied in the Dhumapana group and was the test group. Remaining ten patients were studied in the Svasakutara group and was the control group.

\section{Effect on Severity in Dhumapana Group}

Following the treatment with Dhumapana the mean severity, score of Tamaka Svasa came down to 1.0 from the initial score of 2.4. The difference in mean score before and after the treatment has shown a definite improvement. The improvement was proved highly significant by the paired t- test as shown in the Table 1 .

Table 1: Effect on Severity in patients of Tamaka Svasa in Dhumapana Group

\begin{tabular}{|l|l|l|l|l|l|l|}
\hline Mean & Difference In Means & Paired 't' test & \multicolumn{3}{l|}{} \\
\cline { 1 - 4 } & A.T. & & S.D. & S.E.M. & & P \\
\hline $2.400( \pm 0.699)$ & $1.400( \pm 0.843)$ & 1.000 & 0.667 & 0.211 & 4.743 & $=0.001$ \\
\hline
\end{tabular}

Effect on severity in Svasakutara Rasa Group:

Patients treated with Svasakutara rasa have shown reduction in the severity following treatment. The initial mean score of severity, which was 2.6 before the treatment, came down by 0.7 . This improvement was also found to be statistically significant proving that the change after treatment is not because of a chance factor rather by the definite effect of the medication. A different statistical value related to this analysis is given in the Table 2.

Table 2: Effect on Severity in patients of Tamaka Svasa in Svasakutara rasa Group

\begin{tabular}{|l|l|l|l|l|l|l|}
\hline Mean & Difference In Means & \multicolumn{4}{l}{ Paired't' test } \\
\cline { 1 - 4 } & A.T. & & S.D. & S.E.M. & ' $t$ ' & P \\
\hline $2.600( \pm 0.516)$ & $1.900( \pm 0.568)$ & 0.700 & 0.675 & 0.213 & 3.280 & $=0.010$ \\
\hline
\end{tabular}

Effect on Dyspnoea in patients of Tamaka Svasa in Dhumapana Group: Mean score of severity of dyspnoea before the treatment was 2.0 and this came down to 1.2 following the administration of Dhumapana. An improvement by 0.8 scores following the treatment was proved to be statistically significant by the paired t- test. Or to say the favorable response to the treatment cannot be due to any chance factor rather the Dhumapana is effective in reliving the dyspnoea. The details of the statistical results are presented in the Table. 3

Table 3: Effect on Dyspnoea in patients of Tamaka Svasa in Dhumapana Group:

\begin{tabular}{|l|l|l|l|l|l|l|}
\hline Mean & Difference & Paired't' test & & \\
\hline B.T. & A.T. & In Means & S.D. & S.E.M. & ' $t$ ' & P \\
\hline $2.000( \pm 0.667)$ & $1.200( \pm 0.632)$ & 0.800 & 0.632 & 0.200 & 4.000 & $=0.003$ \\
\hline
\end{tabular}

\section{Effect on Dyspnoea in patients of Tamaka Svasa in} Svasakutara Group: Oral administration of Svasakutara rasa was found to be effective in reliving dyspnoea in patients suffering from Tamaka Svasa. The initial score of dyspnoea, which was 2.0 before the treatment, came down to 1.3 following the treatment. The paired $\mathrm{t}$ - test showed that this change after the treatment is statistically significant. Table 4 shows the full account of the statistical analysis.

Table 4: Effect on Dyspnoea in patients of Tamaka Svasa in Svasakutara Group:

\begin{tabular}{|l|l|l|l|l|l|l|}
\hline Mean & Difference & Paired 't' test & \multicolumn{3}{l|}{} \\
\cline { 2 - 6 } & In Means & S.D. & S.E.M. & 't' & P \\
\hline $2.000( \pm 0.00)$ & $1.300( \pm 0.675)$ & 0.700 & 0.675 & 0.213 & 3.280 & $=0.010$ \\
\hline
\end{tabular}


Effect on Speech in patients of Tamaka Svasa in Dhumapana Group: The difficulty Speech in patients suffering from Tamaka Svasa showed an improvement in once ability to speak following the Dhumapana therapy. The initial mean score of severity of speech was 2.0 and this came down to 1.3 after the treatment. The statistical analysis with paired t- test showed highly significant improvement by the treatment $(\mathrm{P}=0.001)$. The details of the same are given in the Table 5.

Table 5: Effect on Speech in patients of Tamaka Svasa in Dhumapana Group:

\begin{tabular}{|l|l|l|l|l|l|l|}
\hline Mean & Difference & \multicolumn{3}{l}{ Paired 't' test } \\
\cline { 5 - 7 } & A.T. & S.D. & S.E.M. & 't' & P \\
\hline B.T. & $1.300( \pm 0.483)$ & 0.700 & 0.483 & 0.153 & 4.583 & $=0.001$ \\
\hline $2.000( \pm 0.816)$ & & & &
\end{tabular}

Effect on Speech in patients of Tamaka Svasa in Svasakutara Group: Statistically significant improvement was observed in speech after the medication with Svasakutara rasa $(\mathrm{P}=0.015)$. The mean score of severity of speech was 1.7 before the treatment. This initial score came down by 0.5 following the treatment. Statistical details are shown in the Table 6.

Table 6: Effect on Speech in patients of Tamaka Svasa in Svasakutara rasa Group:

\begin{tabular}{|l|l|l|l|l|l|l|}
\hline Mean & Difference & Paired 'T' Test & & \\
\cline { 5 - 7 } & A.T. & In Means & S.D. & S.E.M. & 'T' & P \\
\hline $1.700( \pm 0.483)$ & $1.200( \pm 0.422)$ & 0.500 & 0.527 & 0.167 & 3.000 & $=0.015$ \\
\hline
\end{tabular}

Effect on Cough in patients of Tamaka Svasa in Dhumapana Group: The symptom cough was reduced after the administration of Dhumapana. Before the therapy the mean severity score of cough was 2.4 .
This then came down to 1.4 following the treatment. As shown in the Table 7 the statistical analysis with paired $\mathrm{t}$-test proved significant improvement by the treatment $(\mathrm{P}=0.001)$.

Table 7: Effect on Cough of Tamaka Svasa in Dhumapana Group:

\begin{tabular}{|l|l|l|l|l|l|l|}
\hline Mean & Difference & Paired 't' test & \multicolumn{3}{l|}{} \\
\cline { 1 - 6 } B.T. & A.T. & In Means & S.D. & S.E.M. & 't' & P \\
\hline $2.400( \pm 0.843)$ & $1.400( \pm 0.699)$ & 1.000 & 0.471 & 0.149 & 6.708 & $<0.001$ \\
\hline
\end{tabular}

Effect on Cough in patients of Tamaka Svasa in Svasakutara rasa Group: Remission of the symptom cough was observed following the medication with Svasakutara rasa in 10 patients suffering from Tamaka Svasa. The mean score of severity before the treatment was 1.7 and this then reduced to 1.5 after the medication for a stipulated period. Even then the paired t- test could not confirm the statistical significance of this change $(\mathrm{P}=0.555)$.
Effect on Sputum in patients of Tamaka Svasa in Dhumapana Group: The administration of Dhumapana was found to be very effective in reducing the amount of sputum in patients suffering from Tamaka Svasa. The initial severity score of sputum which was 2.2 came down to 1.3 following the treatment. This improvement was also statistically highly significant as depicted in the Table 8. $(\mathrm{P}<0.001)$.

Table 8: Effect on Sputum in patients of Tamaka Svasa in Dhumapana Group:

\begin{tabular}{|l|l|l|l|l|l|l|}
\hline Mean & Difference & \multicolumn{2}{l|}{ Paired 't' test } \\
\cline { 5 - 7 } & In Means & S.D. & S.E.M. & 't' & P \\
\hline B.T. & A.T. & 0.900 & 0.316 & 0.100 & 9.000 & $<0.001$ \\
\hline
\end{tabular}


Effect on Sputum in patients of Tamaka Svasa in Svasakutara rasa Group: Administration of Svasakutara rasa has not shown reduction in the amount of sputum following medication. The initial symptom score of sputum was 1.6 that then rose to 2.0 after the treatment. However, this change could not be proved to be significant by the statistical methods $(\mathrm{P}<0.223)$ as shown in the Table 9.

Table 9: Effect on Sputum in patients of Tamaka Svasa in Svasakutara Group:

\begin{tabular}{|l|l|l|l|l|l|l|}
\hline Mean & Difference & Paired 't' test & \\
\hline B.T. & A.T. & In Means & S.D. & S.E.M. & 't' & P \\
\hline $1.600( \pm 0.843)$ & $2.000( \pm 0.471)$ & -0.40 & 0.966 & 0.306 & -1.309 & $=0.223$ \\
\hline
\end{tabular}

Effect on Body Position in patients of Tamaka Svasa treated with Dhumapana: The Body position indicating the severity of breathlessness showed remission following the Dhumapana. The initial score of severity of body position before the treatment was 1.9 that came down to 1.1 after the treatment. Analysis of the results by the paired t-test proved that the improvement is statistically significant. $(\mathrm{P}<0.001)$ as shown in the Table 10.

Table 10: Effect on Body Position in patients of Tamaka Svasa treated with Dhumapana

\begin{tabular}{|c|c|c|c|c|c|c|}
\hline \multicolumn{2}{|l|}{ Mean } & \multirow{2}{*}{$\begin{array}{l}\text { Difference } \\
\text { In Means }\end{array}$} & \multicolumn{4}{|c|}{ Paired ' $t$ ' test } \\
\hline B.T. & A.T. & & S.D. & S.E.M. & ' $\mathrm{t}$ ' & $\mathrm{P}$ \\
\hline $1.900( \pm 0.568)$ & $1.100( \pm 0.738)$ & 0.800 & 0.422 & 0.133 & 6.000 & $<0.001$ \\
\hline
\end{tabular}

Effect on Body Position in patients of Tamaka Svasa in Svasakutara rasa Group: The administration of Svasakutara rasa has shown improvement in body position indicating remission of Tamaka Svasa. The mean score of body position that was 1.1 before the treatment reduced to 0.1 following the treatment. However, the improvement is not statistically significant $(\mathrm{P}=0.343)$ the change may be due to chance factor also as shown in the Table 11.

Table 11: Effect on Body Position in patients of Tamaka Svasa in Svasakutara Group:

\begin{tabular}{|l|l|l|l|l|l|l|}
\hline Mean & Difference & Paired 't' test & \\
\cline { 2 - 5 } & A.T. & In Means & S.D. & S.E.M. & ' \\
\hline $1.100( \pm 0.316)$ & $1.000( \pm 0.000)$ & 0.100 & 0.316 & 0.100 & 1.000 & $=0.343$ \\
\hline
\end{tabular}

Effect on Respiratory rate in patients of Tamaka Svasa in Dhumapana Group: The mean Respiratory rate showed a reduction following the treatment with Dhumapana. The initial mean score of 2.1 came down to 1.3 following the treatment. This change is found to be statistically significant as proved by the paired $\mathrm{t}$ test $(\mathrm{P}=0.003)$. Details are given in the Table 12 .

Table 12: Effect on Respiratory rate in patients of Tamaka Svasa in Dhumapana Group:

\begin{tabular}{|l|l|l|}
\hline Mean & Difference \\
\hline B.T. & A.T. & In Means \\
\hline $2.1( \pm 0.568)$ & $1.3( \pm 0.483)$ & 0.800
\end{tabular}

Effect on Respiratory rate in patients of Tamaka Svasa in Svasakutara rasa Group: The oral administration of Svasakutara rasa has significantly brought down the rate of respiration. The study revealed that the mean score of respiratory rates, which was 2.2

\section{Paired ' $\mathrm{t}$ ' test}

\begin{tabular}{l|l|l|l} 
S.D. & S.E.M. & 't' & P
\end{tabular}

\begin{tabular}{l|l|l|l}
0.632 & 0.200 & 4.000 & $=0.003$
\end{tabular}

before the treatment, came down to 1.5 following treatment. Further this change was proved to be statistically significant by the paired $t$ test $(\mathrm{P}=0.025)$. 
Effect on Labored Breathing in Dhumapana Group: Statistically significant improvement was seen in the symptom labored breathing. $(\mathrm{P}=0.015)$.
The initial mean score of labored breathing was 1.5 that came down to 1.0 following the medication. The Table13 gives the details.

Table 13: Effect on Labored Breathing in Dhumapana Group:

\begin{tabular}{l|l|l|l|l|l|l|} 
Mean & Difference & \multicolumn{4}{l}{ Paired 't' test } \\
\cline { 5 - 7 } & In Means & S.D. & S.E.M & 't' & P \\
\hline B.T. & A.T. & 0.500 & 0.527 & 0.167 & 3.000 & $=0.015$ \\
\hline $1.500( \pm 0.527)$ & $1.000( \pm 0.471)$ & & &
\end{tabular}

Effect on Labored Breathing in Svasakutara Group: A reduction by 1.0 in the mean score of labored breathing was observed following treatment with Svasakutara rasa. This improvement was also statistically highly significant as proved by the paired $\mathrm{t}$ - test $(\mathrm{P}<0.001)$.

Effect on Breath Sounds in patients of Tamaka Svasa in Dhumapana Group: The audibility of the breath sounds showed an improvement following employment of Dhumapana. A reduction by 0.5 in the mean score of Breath sounds from the initial score of 2.1 explains the comfort of breathing in patients of Tamaka Svasa following Dhumapana. The improvement by the medication was also proved to be statistically significant $(\mathrm{P}<0.015)$ Table 14 .

Table 14: Effect on Breath Sounds of Tamaka Svasa in Dhumapana Group:

\begin{tabular}{l|l|l|l|l|l|l|} 
Mean & \multicolumn{3}{l}{ Difference } & \multicolumn{4}{l}{ Paired 't' test } \\
\cline { 5 - 7 } & A.T. & In Means & S.D. & S.E.M. & 't' & P \\
\hline B.T. & $1.600( \pm 0.516)$ & 0.500 & 0.527 & 0.167 & 3.000 & $=0.015$ \\
\hline $2.100( \pm 0.738)$ & & & &
\end{tabular}

Effect on Breath Sounds in patients of Tamaka Svasa in Svasakutara Rasa Group: The assessment of breath sounds showed an improvement following the oral administration of Svasakutara rasa. The mean score of breath sounds was 1.7 and 1.0 before and after treatment respectively there by showing a reduction in the mean score by 0.7 . Statistical significance of this improvement was also confirmed by the paired $\mathrm{t}$ - test $(\mathrm{P}<0.001)$.

\section{The spirometric results in dpg and SKG Groups} Effect on Spirometric Parameters of assessment in Dhumapana Group (Absolute value):
FVC, FEV1. PEF and FEV1/FVC were assessed before and after the treatment. The result showed that there was an increase in the lung volumes following the treatment with Dhumapana. The absolute value of the FVC which was 1.856 before the treatment rose to 2.188 following the medication. This improvement was also proved to be statistically highly significant $(\mathrm{P}=0.001)$. The Spirometric evaluation of other absolute values of the lung volume showed statistically significant improvement. Table 15 shows the details of the statistical analysis.

Table 15: Effect on Spirometric Parameters of assessment

\begin{tabular}{|l|l|}
\hline Parameters & B.T (mean \& \pm SEM) \\
\hline FVC Forced vital Capacity & $1.856 \pm 0.275$ \\
\hline FEV1 Forced Exp Volume in 1 sec & $1.226 \pm 0.245$ \\
\hline PEF Peak expiratory Flow & $1.828 \pm 0.382$ \\
\hline FEV1/FVC\% FEV1 as \% of FVC & $66.850 \pm 6.241$ \\
\hline
\end{tabular}

Effect of Dhumapana on the predicted percentage values of spirometric evaluation: The percentage prediction of the lung volumes as assessed by the spi-

\begin{tabular}{|l|l|l|l|l|}
\hline A.T (mean \pm SEM) & S.D & S.E & 't' & P \\
\hline $2.188 \pm 0.268$ & 0.226 & 0.716 & -4.639 & $=0.001$ \\
\hline $1.576 \pm 0.234$ & 0.384 & 0.121 & -2.884 & $=0.018$ \\
\hline $2.809 \pm 0.531$ & 0.593 & 0.188 & -5.229 & $<0.001$ \\
\hline $72.010 \pm 4.238$ & 16.982 & 5.370 & -0.961 & $=0.362$ \\
\hline
\end{tabular}

rometer showed definite improvement in patients treated with Haridra Dhumapana. The \% prediction of FVC was 51.69 before treatment that rose to 61.24 
following Dhumapana. Also, the FEV1 showed marked improvement in the percentage prediction of this volume by the medication. The initial value of the FEV1 was 35.56 and which elevated to 51.43 follow- ing Dhumapana. All the spirometric values that showed increase following medication was also found to be statistically significant as assessed by paired ttest. The details of the same are given in the Table 16.

Table 16: Effect of Dhumapana on the predicted percentage values of spirometric evaluation.

\begin{tabular}{|l|l|l|l|l|l|l|}
\hline Parameters & B.T (mean \& \pm SEM) & A.T (mean \pm SEM) & S.D & S.E & 't' & P \\
\hline FVC Forced vital Capacity & $51.690 \pm 5.757$ & $61.240 \pm 5.786$ & 6.187 & 1.957 & -4.881 & $<0.001$ \\
\hline FEV1 Forced Exp Volume in 1 sec & $39.560 \pm 5.851$ & $51.430 \pm 5.766$ & 12.325 & 3.898 & -3.045 & $=0.014$ \\
\hline PEF Peak expiratory Flow & $24.730 \pm 4.641$ & $38.260 \pm 6.563$ & 8.335 & 2.636 & -5.133 & $<0.001$ \\
\hline FEV1/FVC\% FEV1 as \% of FVC & $82.340 \pm 7.858$ & $88.200 \pm 4.888$ & 20.538 & 6.495 & -0.902 & $=0.390$ \\
\hline
\end{tabular}

Effect on Spirometric Parameters of assessment in Svasakutara rasa Group: The Absolute values of lung volumes as assessed by the spirometer showed improvement in regard to FVC, PEF and FEV1/FVC\% when treated with Svasa -kutara Rasa. In contrast to this the FEV1 showed a marginal reduction. The initial value of FVC was 1.90 which then increased to 2.06 following medication. However, this change was statistically insignificant. The marginal improvement recorded in this group following treatment could not be affirmed by the statistical analysis.

Effect on the predicted percentage values of spirometric evaluation in SKG: The percentage predicted values of the lung volume also showed marginal improvement following treatment by the Svasakutara rasa as assessed by the spirometer. All the parameters which included FVC, FEV1, PEF and FEV1/FVC\% showed improvement following treatment. The initial value of percentage prediction of FVC was 54.34 and the same rose to 59.30 following medication with Svasakutara rasa. The other spirometric results also showed similar tendency of increase. However, the statistical analysis revealed that these changes happened may be because of chance factor or due to sampling variability. The details are shown in the Table 17.

Table 17: Effect on the predicted percentage values of spirometric evaluation in SKG.

\begin{tabular}{|l|l|l|l|l|l|l|}
\hline Parameters & B.T (mean \& \pm SEM) & A.T (mean \pm SEM) & S.D & S.E & 't' & P \\
\hline FVC Forced vital Capacity & $54.340 \pm 4.632$ & $59.300 \pm 4.233$ & 9.658 & 3.054 & -1.624 & $=0.139$ \\
\hline FEV1 Forced Exp Volume in 1 sec & $39.580 \pm 4.292$ & $45.440 \pm 3.800$ & 8.039 & 2.542 & -2.305 & $=0.047$ \\
\hline PEF Peak expiratory Flow & $26.220 \pm 3.314$ & $32.180 \pm 4.176$ & 7.942 & 2.511 & -2.373 & $=0.042$ \\
\hline FEV1/FVC\% FEV1 as \% of FVC & $75.240 \pm 4.139$ & $79.930 \pm 5.251$ & 16.946 & 5.359 & -0.875 & $=0.404$ \\
\hline
\end{tabular}

\section{Overall effect of Dhumapana and Svasakutara rasa} in patients of Tamaka Svasa: After the completion of the 10 days course of medication in the two groups the overall assessment of the patients was made as discussed in the assessment criteria. The analysis revealed that no patients recorded complete relief both in the Dhumapana group and Svasakutara rasa group. Moderate remission of the illness was found in $20 \%$ of the patients in Dhumapana group. Contrary to this, no patients showed moderate remission in the Svasakutara rasa group. $40 \%$ of the patients recorded average remission in patients treated with Dhumapana as against $50 \%$ of the patients showing the same average remission in the Svasakuthara Rasa group. No remission of the illness was observed in $40 \%$ and $50 \%$ of patients in Dhumapana group and Svasakutara rasa group respectively as shown in the Table 18 . 
Table 18: Overall effect in two groups:

\begin{tabular}{|l|l|l|l|l|l|l|}
\hline Effect & DPG & $\%$ & SKG & $\%$ & Total & $\%$ \\
\hline Complete remission & 0 & 0 & 0 & 0 & 0 & 0 \\
\hline Moderate remission & 2 & 20 & 0 & 0 & 2 & 10 \\
\hline Average remission & 4 & 40 & 5 & 50 & 9 & 45 \\
\hline No remission & 4 & 40 & 5 & 50 & 9 & 45 \\
\hline
\end{tabular}

\section{DISCUSSION}

The principles of treatment that are adapted in Tamaka Svasa include Sodhana, Samana, Bruhmana and Rasayana cikitsa. Tamaka Svasa is typically an episodic illness. Therefore, the treatment differs during the attack of Tamaka Svasa and in between the attacks. Liquefaction of the Sleshma, expectoration of the sputum and Srotomardava Cikitsa forms the key treatment during the attack of the illness. This is achieved by Abhyanga and Swedana of the chest, then Kapha utklesana Ahara followed by Vamana, then followed by Dhumapana and Shamana treatment. These therapeutic procedures remove the Sleshma obstructing the Pranavayu, as well as render Mardava of Pranavaha Srotas facilitating free movement of Pranavayu in the Pranavaha Srotas. In between the attacks, the treatment is planned to prevent the further attacks, to eliminate the Kha-vaigunyata, and to improve the immunity of the Pranavaha Srotas. This is achieved by Virecana karma, Bruhmana Cikitsa and Rasayana cikitsa.

The purpose of Shamana Cikitsa is to ensure Kapha vilayana, Kapha Nissarana, Kasaghna, Srotho mardavakarana, Vatahara, Kaphahara and Brumhana effects and is mostly achieved by the oral medication. Considering these principles of treatment, the Dhumapana and oral medication with Svasakutara rasa is taken for this study. To evaluate the effect of this Herbal combination in patients of Tamaka Svasa, this single blind comparative clinical study is planned. Test group patient are subjected to Dhumapana and oral medication with Svasakutara Rasa. A control group treated with Svasakutara rasa in prescribed doses is maintained to assess the effect of the treatment.

\section{CONCLUSION}

Among the 20 patients taken for this study maximum number of patients belonged to the age group of 12 to 24 years. Remission of the severity of the illness was recorded in both the Dhumapana and Svasakutara groups. Improvement observed in the Dhumapana group was statistically highly significant $(\mathrm{P}<0.001)$. While in Svasakutara group, though improvement was observed the statistical analysis by the paired t- test proved insignificant, Best improvement was recorded in the Dhumapana group in comparison to the Svasakutara rasa group in the mental status of the patients suffering from Tamaka Svasa. However, the unpaired t- test did not show statistically significant change in two groups when compared $(\mathrm{P}=0.250)$. FVC, FEV1. $\mathrm{PEF}$ and FEV1/FVC were assessed before and after the treatment. The result sowed that there was an increase in the lung volumes following the treatment with Dhumapana. The absolute value of the FVC which was 1.856 before the treatment rose to 2.188 following the medication. This improvement was also proved to be statistically highly significant $(\mathrm{P}=0.001)$. The spirometric evaluation of other Absolute values of the lung volume showed statistically significant improvement. The analysis revealed that no patients recorded complete relief both in the Dhumapana group and Svasakutara Rasa group.

Moderate remission of the illness was found in $20 \%$ of the patients in Dhumapana group. Contrary to this no patients showed moderate remission in the Svasakutara rasa group. $40 \%$ of the patients recorded average remission in patients treated with Dhumapana as against $50 \%$ of the patients showing the same average remission in Svasa kutara Rasa group. No remission of the illness was observed in $40 \%$ and $50 \%$ of patients in Dhumapana group and Svasakutara rasa group respectively. The total duration of the treatment in both the groups was 10 days. During this period of 
medication none of the patients developed any untoward symptoms that can be labeled as side effect. Therefore, the medication in this therapeutic Doshage seems to be safe. Form the above citations it is clear that the treatments in both the groups have resulted in improvement in regard to almost all the criteria of assessment. Sroto mardavakarana, Kapha harana, Kapha vilayana, Kapha nissarana and Kasaghna are the therapeutic effects of medication that are essential for the remittance of the illness. These therapeutic effects ensure clarity of the air passages reverting the Pranavilomata of Tamaka Svasa. The reduction in all the criteria of assessment implies that this would be a complete treatment. The showed that the improvement in patients suffering from Tamaka Svasa was better in patients treated with Dhumapana in comparison to the patients treated with Svasakutara rasa. This is to say that the combination treatment of Dhumapana and Svasakutara rasa in test group is more efficacious than the oral medication of Svasakutara rasa alone. This research work is presented with the hope that this will further widen the scope for further research and advancement in this aspect of Ayurvedic medicine, for the betterment of mankind.

\section{REFERENCES}

1. Vaidya jadavaji trikamiji Acharya, Agnivesha; Charaka, Charaka Samhita chikitsa sthana chapter - 17 verse- 61 Edition 2009 published by Chaukhambha Surabharathi Prakashana Varanasi. Page. No. 535

2. Robert Clive, Herald of Health, July-2004. Oriental Watchman Publishing house Pune.

3. Sri Gayadasacharya, Susruta; Sushruta Samhita with Nibandhasarasangraha Commentary of Sri Dalhana Acharya and Nyana Chandrika panjika uttartantram chapter 51, verse- 8 edited by Dr. keval Krishna thakral, Reprinted edition 2017 published by Chaukhambha orientaliya, Varanasi. Page no. 485

4. Acharya Vijayarakshita and Srikantadatta and Sanskrit commentary by Brahmanand tripathi, Madhavakara; Madhava Nidanam Roga-viniscaya, Madhukosha chapter- 12 verse-15 by vol-1 edition-2008. Chaukhambha surbharti prakashan, page. No. 388

5. Vaidya jadavaji trikamiji Acharya, Agnivesha; Charaka, Charaka Samhita chikitsa sthana chapter - 17, verse- 55-56, Edition 2009, published by Chau- khambha Surabharathi Prakashana Varanasi. Page. No. 535

6. Vaidya jadavaji trikamiji Acharya, Agnivesha; Charaka, Charaka Samhita chikitsa sthana chapter - 17, verse- 19-20 Edition 2009, published by Chaukhambha Surabharathi Prakashana Varanasi. Page. No. 533.

7. Sri Gayadasacharya, Susruta; Sushruta Samhita with Nibandhasarasangraha Commentary of Sri Dalhana Acharya and Nyana Chandrika panjika uttartantram chapter 51-verse- 6 edited by Dr. keval Krishna thakral, Reprinted edition 2017 published by Chaukhambha orientaliya Varanasi. Page no. 485.

8. Pandit Hari Sadasiva sastri Paradakara bhisagacarya, Vaghbata; Astanga Hridaya with commentaries Sarvangasundara of Arunadutta and Ayurveda Rasayana of Hemadri, chapter 4 verse 4 Edition 2018 published by Chaukhamba Sanskrit Sansthan varanasi. Page no. 472

9. Acharya Vijayarakshita and Srikantadatta and Sanskrit commentary by Brahmanand tripathi, Madhavakara; Madhava Nidanam Roga-viniscaya Madhukosha chapter- 12 verse-36 vol-1 edition -2008. Chaukhambha surbharti prakashan, page. No. 393.

10. Ed: Asui, Brauneald, Iselbachar, Wilson, Martin, Kasher Hauser and Lango Harrison's Principles of Internal Medicine, vol. 2 (2001), 15 ${ }^{\text {th }}$ edition, New York. Page no. 1420 .

11. Vaidya jadavaji trikamiji Acharya, Agnivesha; Charaka, Charaka Samhita chikitsa sthana chapter - 17, verse- 57, Edition 2009, published by Chaukhambha Surabharathi Prakashana Varanasi. Page. No. 535

12. Vaidya jadavaji trikamiji Acharya, Agnivesha; Charaka, Charaka Samhita chikitsa sthana chapter - 17, verse- 58, Edition 2009, published by Chaukhambha Surabharathi Prakashana Varanasi. Page. No. 535

13. Vaidya jadavaji trikamiji Acharya, Agnivesha; Charaka, Charaka Samhita chikitsa sthana chapter - 17, verse- 56, Edition 2009, published by Chaukhambha Surabharathi Prakashana Varanasi. Page. No. 535

14. Vaidya jadavaji trikamiji Acharya, Agnivesha; Charaka, Charaka Samhita chikitsa sthana chapter - 17, verse- 55, Edition 2009, published by Chaukhambha Surabharathi Prakashana Varanasi. Page. No. 535

15. Joshi Venimadhavashastri, Narayan Edt; Ayurvedeeya Shabdhakosha: 'Hari Joshi publishers', Department of Culture \& Literature (Sahitya) Government of Maharasthra, Mumbai. Page no. 428

16. Vaidya jadavaji trikamiji Acharya, Agnivesha; Charaka, Charaka Samhita sutra sthana chapter - 5, verse27-32, Edition 2009, published by Chaukhambha Surabharathi Prakashana Varanasi. Page. No. 40. 


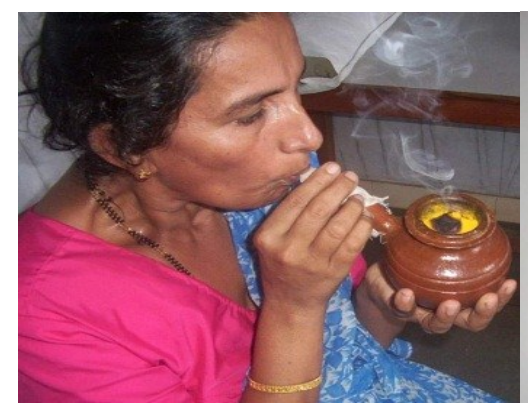

Dhumapana

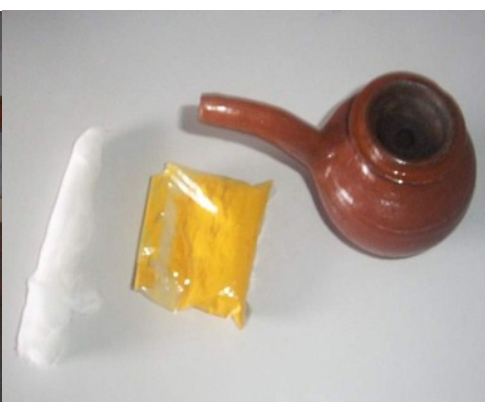

Meterials

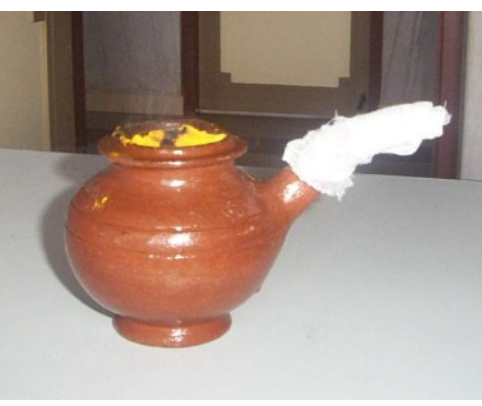

Dhumayantra

\section{Source of Support: Nil}

\section{Conflict of Interest: None Declared}

How to cite this URL: Sankramma Patil et al: Effect of Haridra Dhumapana And Svasakutara Ras In Tamaka Svasa - A Cmparative Study. International Ayurvedic Medical Journal \{online 2021 \{cited January, 2021\} Available from: http://www.iamj.in/posts/images/upload/2645_2657.pdf 